\title{
Identifikasi Senyawa Metabolit Sekunder, Uji Antimikroba dan Antioksidan Ekstrak Akar Gantung Hornstedtia Scyphifera Var. Fusiformis Holttum (Sijangkang)
}

\author{
Adlis Santoni ${ }^{*}$, Mai Efdia ${ }^{a}$ Akmel Suhadaa \\ aLaboratorium Kimia Bahan Alam, Jurusan Kimia Fakultas Matematika dan Ilmu Pengetahuan Alam, \\ Universitas Andalas
}

Corresponding Author:

Adlis Santoni

adlis_1962@yahoo.com

Received: April 2017

Accepted: September 2019

Published: September 2019

(C)Adlis Santoni et al. This is an open-access article distributed under the terms of the Creative Commons Attribution License, which permits unrestricted use, distribution, and reproduction in any medium, provided the original author and source are credited.

\begin{abstract}
Hornstedtia scyphifera var. fusiformis Holttum is endemic plant of Zingiberaceae family that distributed in Sumatera. Hornstedtia scyphifera var. fusiformis Holttum contained some secondary metabolite such as phenolic, saponin, triterpenoid and alkaloid. The biological activity of methanol, ethyl acetate, and n-hexane extracts from Hornstedtia scyphifera var. fusiformis Holttum suspended roots was tested for antibacterial and antioxydant activity. Antioxidant activity was analized by DPPH method. The antibacterial activity was tested by used disk difussion method againts Staphylococcus aureus bacteria (gram-positive bacteria) and Escherichia coli (gram-negative bacteria). Almost all of Hornstedtia scyphifera var. fusiformis Holttum suspended roots extract were given antibacterial activity, nonetheless the biggest inhibition zone of Escherichia coli that was inhibited by n-hexane and ethyl acetate extracts which have inhibtion zone $10 \mathrm{~mm}$ at concentration $500 \mathrm{mg} / \mathrm{L}$ and also againts Staphylococcus aureus, the biggest inhibition by ethyl acetate and n-hexane extracts which have inhibition zone $10.30 \mathrm{~mm}$ at concentration $500 \mathrm{mg} / \mathrm{L}$. Among all extracts tested, methanol extract of the possessed moderate free radical scavenging activity with $I C_{50}=$ $51.89 \mathrm{mg} / \mathrm{L}$.
\end{abstract}

Keywords: Hornstedtia scyphifera var. fusiformis Holttum; antibacterial; antioxidant

\section{Pendahuluan}

Penggunaan tumbuhan dan herbal sebagai pilihan obat telah menjadi fenomena yang universal. Sekarang ini, sebanyak $80 \%$ masyarakat dunia telah memilih obat tradisional sebagai kebutuhan perawatan kesehatan primer. Kemajuan penelitian di lapangan yang terus berkelanjutan telah memperjelas bahwa banyak spesies tanaman yang dimanfaatkan oleh masyarakat sebagai pilihan dalam dunia industri obat. Sebagian besar terapi tradisional juga melibatkan penggunaan ekstrak tanaman sebagai dasar penyembuhan $^{[1]}$.

Salah satu famili tumbuhan yang telah banyak dimanfaatkan sebagai bahan obat adalah Zingiberaceae atau lebih dikenal sebagai famili rimpang-rimpangan. Zingiberaceae terdiri dari lebih kurang 52 genus dan 1300 jenis spesies tumbuhan. Beberapa uji fitokimia dari tanaman ini sudah banyak dilaporkan memiliki aktivitas biologi yang menarik, termasuk laporan terkait 
ekstrak Zingiberacea yaitu antimikroba, antioksidan, antikanker dan efek stimulan terhadap sistem imun ${ }^{[2]-[4]}$.

Hornstedtia merupakan salah satu genus dari Zingiberaceae yang memiliki aktivitas biologi antimikroba dan antioksidan. Aktivitas beberapa spesies Hornstedtia seperti Hornstedtia scyphifera, Hornstedtia ophiuschus dan Hornstedtia striolata terhadap bakteri Staphylococcus aureus, Escherichia coli, dan jamur Candida albican telah banyak diteliti. Beberapa ekstrak Hornstedtia leonurus. Retz juga telah dilaporkan memiliki aktivitas antioksidan ${ }^{[5],[6]}$. Namun, kemampuan antioksidan dan antibakteri dari ektrak tanaman Hornstedtia scyphifera var fusiformis yang merupakan salah satu varian dari Hornstedtia scyphifera yang terdistribusi di Sumatera Barat belum ada yang melaporkan ${ }^{[7]}$. Hal ini menarik perhatian untuk diuji dan diteliti.

\section{Metodologi Penelitian}

\section{Bahan kimia}

Bahan yang digunakan pada penelitian ini adalah sampel kering akar gantung Hornstedtia scyphifera var fusiformis Holttum, pelarut teknis yang telah didistilasi yaitu heksana, etil asetat, dan metanol. Aluminium foil, akuades, bakteri Escherichia coli dan Staphylococcus aureus, dimetilsulfoksida, gentamicyn, media MullerHilton Agar, DPPH (1,1-difenil-2pikrilhidrazil), Whatman No. 40, alkohol 75\%, asam askorbat, pereaksi Mayer untuk identifikasi alkaloid, pereaksi Liebermann Burchard (anhidrida asetat dan asam sulfat pekat), sianidin test (bubuk magnesium dan asam klorida pekat), besi (III) klorida, plat KLT dan $\mathrm{NaOH} 1 \%$.

\section{Peralatan}

Alat yang digunakan pada penelitian ini adalah corong, rotary evaporator, botol reagen, botol vial, neraca analitik, cawan petri, micropipette, gelas piala, erlenmeyer, tabung eppendorf, microplate, labu ukur $10 \mathrm{~mL}$, labu ukur $100 \mathrm{~mL}$, pipet gondok $2 \mathrm{~mL}$, pipet gondok $5 \mathrm{~mL}$, pipet takar, Lampu UV ( $\lambda 254$ dan $356 \mathrm{~nm}$ ), laminar air flow, dan spektrofotometer UV-VIS.

\section{Prosedur penelitian}

\section{Identifikasi metabolit sekunder}

Untuk identifikasi senyawa alkaloid, sebanyak 1 gram ekstrak akar gantung ditambah dengan 3 tetes amonia 10\% dan 1,5 mL kloroform, lalu dikocok. Lapisan kloroform diambil kemudian dilarutkan dalam $1 \mathrm{~mL}$ asam sulfat $2 \mathrm{~N}$, kemudian dikocok. Setelah itu, ekstrak ditambahkan dengan pereaksi Meyer. Terbentuknya endapan putih menandakan adanya senyawa alkaloid. Untuk identifikasi senyawa steroid dan triterpenoid, sebanyak sebanyak 1 gram ekstrak metanol akar gantung ditambah dengan $2 \mathrm{~mL}$ kloroform dalam tabung reaksi, kemudian diteteskan ke dalam plat tetes, dan dibiarkan sampai kering. Setelah itu, ditambahkan dengan 1 tetes pereaksi Liebermann-Burchard. Terbentuknya warna merah menandakan adanya senyawa triterpenoid dan terbentuknya warna biru atau ungu menandakan adanya senyawa steroid. Untuk identifikasi senyawa saponin, sebanyak 1 gram ekstrak akar gantung ditambah dengan $20 \mathrm{~mL}$ akuades, kemudian dipanaskan selama 5 menit. Larutan dituang ke dalam tabung reaksi dalam keadaan panas. Larutan diambil sebanyak $10 \mathrm{~mL}$, kemudian dikocok kuat secara vertical selama 10 detik. Adanya saponin ditandai dengan terbentuknya busa yang stabil setinggi $1-10 \mathrm{~cm}$ selama 10 menit dan tidak hilang pada saat ditambahkan dengan satu tetes $\mathrm{HCl} 2 \mathrm{~N}^{[8]}$.

\section{Ekstraksi}

Sampel halus ( $\pm 120 \mathrm{~g}$ ) diekstraksi dengan cara maserasi menggunakan pelarut dengan tingkat kepolaran yang berbeda yaitu n-heksan, etil asetat dan metanol secara bertahap. Maserasi dilakukan sebanyak 3 kali untuk masingmasing pelarut. Setiap maserat yang diperoleh diuapkan pelarutnya dengan rotary evaporator pada suhu $40{ }^{\circ} \mathrm{C}$, kemudian didapatkan ekstrak pekat dan ditimbang. Kemudian Sampel halus ( $\pm 10 \mathrm{~g}$ ) diekstraksi dengan metanol (3 kali) kemudian dilanjutkan dengan penguapan pelarut dengan rotary evaporator sehingga diperoleh ekstrak pekat yang disebut sebagai sampel awal. 


\section{Pengujian aktivitas antibakteri}

Aktvitas antibakteri ditentukan dengan metode difusi cakram. Media yang digunakan adalah media Mueller-Hilton agar. Kultur bakteri Staphylococcus aureus dan Escherichia coli yang sudah dimalamkan ditepatkan dengan standar kekeruhan McFarland (5\%). Sebanyak $1 \mathrm{mg}$ sampel uji dilarutkan dalam $100 \mu \mathrm{L}$ DMSO dan ditambah $900 \mu \mathrm{L}$ akuades untuk mendapatkan konsentrasi induk $1000 \mathrm{mg} / \mathrm{L}$, yang kemudian diencerkan untuk mendapat variasi konsentrasi 125, 250 dan $500 \mathrm{mg} / \mathrm{L}$. Inokulat disuspensikan sebanyak $200 \mu \mathrm{L}$ ke atas media Mueller-Hilton yang sudah padat dan diratakan menggunakan perata bakteri. Larutan uji disuspensikan sebanyak $20 \mu \mathrm{L}$ pada kertas cakram yang kemudian diletakkan di atas media yang sudah tertebar inokulat. Zona bening yang terbentuk disekitar kertas cakram ditentukan sebagai aktivitas antibakteri. Kontrol positif yang digunakan adalah gentamycin $20 \mu \mathrm{g} / \mathrm{mL}$ dan kontrol negatifnya yaitu DMSO 1\%.

\section{Aktivitas antioksidan dengan metode DPPH}

Metoda ini dikenalkan oleh Tagashira dan Ohtake, 1998 dengan beberapa modifikasi[9]. Masing-masing sampel (1000 mg/L) diencerkan dalam metanol untuk mendapatkan konsentrasi 100, 50, 25, 12,5 dan 6,25 ppm. Sebanyak $3 \mathrm{~mL}$ larutan DPPH $0,1 \mathrm{mM}$ ditambahkan ke dalam $2 \mathrm{~mL}$ masing-masing konsentrasi larutan sampel dan dibiarkan bereaksi selama 30 menit pada suhu kamar ${ }^{[9]}$. Setelah 30 menit, absorban dari masing-masing campuran diukur dengan Spektrofotometer UV-Vis pada panjang gelombang $517 \mathrm{~nm}$. Campuran larutan DPPH dan metanol digunakan sebagai blanko, sedangkan asam askorbat digunakan sebagai standar antioksidan. Persentasi inhibisi dihitung dengan cara:

$$
\mathrm{I} \%=[(\text { Ablank }- \text { Asampel }) / \text { Ablank }] \times 100 \%
$$

Nilai IC50 ditentukan setiap konsentrasi masing-masing sampel memberikan 50\% absorban yang ditunjukkan oleh blanko.

\section{Hasil dan Diskusi}

\section{Identifikasi metabolit sekunder}

Hasil uji profil fitokimia pada bagian akar gantung Hornstedtia scyphifera var. fusiformis Holttum tertera pada Tabel 1.

Tabel 1. Hasil Uji Fitokimia

\begin{tabular}{|c|c|c|c|c|c|c|}
\hline \multirow[t]{2}{*}{ No. } & \multirow{2}{*}{$\begin{array}{c}\text { Kandungan } \\
\text { Kimia }\end{array}$} & \multirow[b]{2}{*}{ Pereaksi } & \multirow{2}{*}{$\begin{array}{c}\text { Sampel } \\
\text { Awal }\end{array}$} & \multicolumn{3}{|c|}{ Fraksi } \\
\hline & & & & Metanol & $\begin{array}{c}\text { Etil } \\
\text { Asetat }\end{array}$ & $\begin{array}{c}\text { n- } \\
\text { Heksan }\end{array}$ \\
\hline 1. & Fenolik & Besi (III) klorida & + & + & + & - \\
\hline 2. & Flavonoid & $\begin{array}{l}\text { Sianidin Tes } \\
(\mathrm{HCl} / \text { bubuk } \mathrm{Mg})\end{array}$ & - & - & - & - \\
\hline 3. & Saponin & $\begin{array}{l}\text { Akuades/HCl } \\
\text { pekat }\end{array}$ & + & + & - & - \\
\hline 4. & Triterpenoid & $\begin{array}{l}\text { Liebermann- } \\
\text { Burchard }\end{array}$ & + & - & + & + \\
\hline 5. & Steroid & $\begin{array}{l}\text { Liebermann- } \\
\text { Burchard }\end{array}$ & - & - & - & - \\
\hline 6. & Alkaloid & Mayer & + & + & - & + \\
\hline 7. & Kumarin & $\begin{array}{l}\text { Natrium } \\
\text { hidroksida 1\% }\end{array}$ & - & - & - & - \\
\hline
\end{tabular}

Keterangan $:(+)=$ teridentifikasi $(-)=$ tidak teridentifikasi

Tabel 2. Hasil Uji Aktvitas Antibakteri Ekstrak akar gantung 


\begin{tabular}{cccc}
\hline \multirow{2}{*}{ Ekstrak } & \multirow{2}{*}{ Konsentrasi Uji $(\mathbf{m g} / \mathbf{L})$} & Diameter Zona Bening $(\mathbf{m m})$ & Pertumbuhan Bakteri \\
\cline { 3 - 4 } & & S. aureus & E. coli \\
\hline \multirow{2}{*}{ Metanol } & 125 & 8,67 & 8,3 \\
& 250 & 9,67 & 9 \\
& 500 & 10 & 9,3 \\
\hline Etil Asetat & 125 & 8,30 & 8,67 \\
& 250 & 9 & 8,83 \\
& 500 & 10,30 & 10 \\
\hline Heksan & 125 & 9,3 & 8,67 \\
& 250 & 10 & 9,67 \\
& 500 & 10,30 & 10 \\
\hline
\end{tabular}

Tabel 3. Aktifitas antioksidan dari ekstrak akar gantung

\begin{tabular}{cc}
\hline Ekstrak & IC $_{50}(\mathbf{m g} / \mathbf{L})$ \\
\hline Heksan & 394,14 \\
\hline Etil asetat & 111,52 \\
\hline Metanol & 51,89 \\
\hline Asam askorbat & 2,56 \\
\hline
\end{tabular}

Hasil uji fitokimia menunjukkan akar gantung Hornstedtia scyphifera var. fusiformis Holttum mengandung beberapa golongan metabolit sekunder seperti fenolik, saponin, triterpenoid dan alkaloid. Sedangkan golongan flavonoid tidak teridentifikasi pada akar gantung Hornstedtia scyphifera var. fusiformis Holttum yang ditandai dengan tidak terbentuknya warna merah saat ditambahkan $\mathrm{HCl}$ pekat dan serbuk Mg. Demikian juga halnya dengan steroid dan kumarin, karena pada pengujian steroid tidak terbentuk cicin hijau dengan penambahan $\mathrm{H}_{2} \mathrm{SO}_{4}$ pekat dan tidak adanya noda yang berfluoresensi pada plat KLT di bawah sinar UV $365 \mathrm{~nm}$ dan setelah disemprot $\mathrm{NaOH} 1 \%$.

Pengujian Aktivitas Antibakteri

Pengujian aktivitas antibakteri dilakukan terhadap bakteri gram positif yaitu Staphylococcus aureus dan bakteri gram negatif yaitu Escherichia coli.Aktivitas masingmasing ekstrak terhadap bakteri Staphylococcus aureus dan bakteri Escherichia coli dapat dilihat pada Tabel. 2.

Zona bening yang terbentuk pada masingmasing bakteri uji oleh semua ekstrak untuk setiap variasi konsentrasi berbeda. Hasil pengukuran zona bening terlihat bahwa zona hambat paling besar untuk bakteri Escherichia coli dan Staphylococcus aureus dengan konsentrasi yang sama yaitu $500 \mathrm{mg} / \mathrm{L}$ oleh ektrak n-heksan dan etil asetat. Untuk Escherichia coli, ekstrak n-heksan dan etil asetat memiliki daerah hambat sebesar $10 \mathrm{~mm}$. Begitu juga ekstrak n-heksan dan etil asetat menunjukan aktifitas yang sama yaitu 10,30 mm terhadap bakteri Staphylococcus aureus. Hal ini disebabkan oleh karena pada ekstrak etil asetat dan n-heksan, kandungan senyawa tritepenoid yang terdapat pada kedua ekstrak tersebut lebih tinggi dibandingkan pada ekstrak metanol. Diduga senyawa golongan triterpenoid ini bertanggung jawab terhadap aktifitas antibakteri dari ekstrak tersebut.

\section{Uji aktivitas antioksidan dengan metode DPPH}

Semua ekstrak diuji aktivitas antioksidannya dengan menggunakan metoda DPPH dan juga digunakan asam askorbat sebagai kontrol positif dan dapat dilihat pada Tabel 3.

Ekstrak metanol memiliki aktivitas antioksidan yang paling bagus diantara ekstrak yang lainnya dengan nilai $I C_{50}=51,89 \mathrm{mg} / \mathrm{L}$ dan digolongkan sebagai antioksidan yang aktif berdasarkan rentang aktivitas antioksidan yang 
dikemukakan oleh Shekar. Sedangkan ekstrak etil asetat digolongkan sedang dan esktrak nheksan digolongkan lemah berdasarkan nilai IC 50 yang didapat.

\section{Kesimpulan}

Golongan metabolit sekunder yang terkandung dalam bagian akar gantung Hornstedtia scyphifera var. fusiformis Holttum adalah fenolik, saponin, triterpenoid dan alkaloid. Semua ekstrak akar gantung Hornstedtia scyphifera var. fusiformis Holttum memiliki aktivitas terhadap Staphylococcus aureus dan Escherichia coli dan rata-rata memberikan zona hambat paling besar pada kosentrasi $500 \mathrm{mg} / \mathrm{L}$ untuk masingmasing ekstrak. Aktivitas antioksidan yang paling aktif diberikan oleh ekstrak metanol dengan $I C_{50}=51,89 \mathrm{mg} / \mathrm{L}$ diantara ekstrak lainnya.

\section{Daftar Pustaka}

1. Karumaran, S., Nethaji, S. \& Rajakumar, R., Antimicrobial and antioxidant activity of leaf extracts of Aegle marmelos. 7(3): 205208 (2016).

2. Julie, J. \& Ernest, T. J., Evaluation of Antioxidant Potential of Rhizome Extracts of Two Species of Alpinia Roxb. (Zingiberacea). (March): (2019).
3. Kamazeri, T. S. A. T., Samah, O. A., Taher, M., Susanti, D. \& Qaralleh, H., Antimicrobial activity and essential oils of Curcuma aeruginosa, Curcuma mangga, and Zingiber cassumunar from Malaysia. Asian Pac. J. Trop. Med., 5(3): 202-209 (2012).

4. Natta, L., Orapin, K., Krittika, N. \& Pantip, B., Essential oil from five Zingiberaceae for anti food-borne bacteria. Int. Food Res. J., 15(3): 337-346 (2008).

5. Holttum, R. E., The zingiberaceae of the Malay Peninsula. Gard. Bull. Singapore, 13(1): 1-249 (1950).

6. Hashim, S. E., Sirat, H. M. \& Yen, K. H., Chemical compositions and antimicrobial activity of the essential oils of Hornstedtia havilandii (Zingiberaceae). Nat. Prod. Commun., 9(1): 119-120 (2014).

7. Jani, N. A., Ibrahim, N., Hashim, S. E. \& Sirat, H. M., Antimicrobial and Antioxidant Activities of Hornstedtia leonurus Retz. Extracts. J. Sci. Technol., 7(2): (2015).

8. Lestari, T., Nurainas, N. \& Syamsuardi, S., Studi Morfometrik Hornstedtia leonurus (J. Koenig) Retz.(Zingiberaceae) dan Kerabat Dekatnya dalam Tribe Alpiniae di Sumatera Barat. J. Biol. Univ. Andalas, 4(3): (2015).

9. Tagashira, M. \& Ohtake, Y., A new antioxidative 1, 3-benzodioxole from Melissa officinalis. Planta Med., 64(06): 555558 (1998). 